\title{
Foreign Financial Institution Equities: Returns From Emerging Markets And Developed Markets Differ
}

\author{
R. Stephen Elliott \\ College of Business \\ Northwestern State University \\ Natchitoches, LA 71497 \\ Phone: (318) 357-5700 \\ e-mail: elliott@nsula.edu \\ Mark Schaub \\ College of Business \\ Northwestern State University \\ Natchitoches, LA 71497 \\ Phone: (318) 357-5704 \\ e-mail: schaubm@nsula.edu
}

\section{Introduction}

With the vicissitude of the capital markets, investors continually seek new and innovative techniques that will identify securities that outperform the market. In addition to the usual fundamental and technical analysis, the international markets may provide enhanced profit potential. Investors may purchase securities of foreign companies to gain greater diversity and new investment opportunities.

To eliminate much of the difficulties of purchasing foreign stock directly, individuals and businesses may purchase financial instruments known as American Depository Receipts (ADRs) which are traded like domestic shares of stock on the overthe-counter market, American Stock Exchange, and the New York Stock Exchange. American Depository Receipts are certificates created by large U.S. banks that represent ownership of a certain number of shares of stock of a foreign company denominated in dollars. The bank holds the original foreign stock in a trust and allows the owner of the ADR to receive dividends in U.S. dollars. The market value of the ADRs change with the market value of the underlying foreign stock held in trust (Besley and Brigham, 1999). About 1700 ADRs are now available in the United States (Brigham and Ehrhardt, 2005).

Although ADRs have gained popularity since J.P. Morgan introduced them in 1927, ADRs include unique differences in risk. First, the underlying firms have a high degree of asymmetric information not easily obtained by domestic investors. Legal standards in foreign countries may not demand a comparable level of honesty or financial disclosure expected from American firms. Information that is disclosed may not be written in English. Second, the price movements of ADRs reflect not only the economy 
of the foreign country, but also the currency fluctuations (Liang and Mougoue, 1996). Third, voting rights do not pass to the owners of ADRs therefore eliminating control of the company.

On the other hand, ADRs provide the advantages of no brokerage mandated trading minimums and no need to convert dollars into foreign current to buy the securities. Furthermore, companies offering ADRs tend to be large, well established companies which may reduce the investment risk. Traded in a larger and more efficient market, the shares tend to have greater liquidity. Jiang (1998) and Officer and Hoffmeister (1988) suggest these advantages are important to ADR investors who seek international diversification. Recently ADRs have been especially helpful in providing funding for acquisitions and multi-billion dollar buy-outs of foreign companies such as the British Petroleum acquisition of Amoco Corporation (Drexhage, 1998, and Shearer, 2001).

Studies tend to show mixed results on the performance of ADRs. Callaghan, Kleiman and Sahu (1999) suggests ADRs yield significantly positive market-adjusted returns in both the short-term and long-term investment horizons with first year cumulative abnormal returns of $19.6 \%$ and that ADRs from emerging markets $34.37 \%$ first year cumulative abnormal return) outperform those from developed countries. Sundaram and Logue (1996) likewise find significant positive abnormal returns in ADR early trading. On the other hand, Foerster and Karolyi (2000) find ADRs under-perform comparable firms by $8 \%-15 \%$ during the first three years following the date of issue. Ritter (1984, and 1991) concludes that global equity offerings under-perform the market in the long run. Martell, Rodriguez and Webb (1999) find that price changes of the underlying shares for ADRs from emerging markets are not significant while Jayaraman, Shastri and Tandon (1993) find the variances of the underlying shares from developed markets to be significantly higher after listing the ADRs. This study attempts to address the conundrum of investing in foreign financial companies.

\section{The Problem}

The problem of this study is to determine whether foreign finance industry equities generally outperform the market over a three-year period and to determine whether foreign financial institution equities from developed markets differ from those of emerging markets. A secondary part of the problem is to determine whether initial public offerings (IPOs) differ from seasoned equity offerings (SEOs) for foreign financial institutions.

\section{Data}

This study examines the long-run abnormal returns from a sample of 58 foreign financial institution equities traded on the New York Stock Exchange from January 1, 1987 through September 30, 2000. Of the 58 ADRs, 16 are from emerging markets and 42 are from developed markets; 31 issues are IPOs and 27 are SEOs. Table 1 identifies the countries and the number of stock issues from each. Twenty-two countries are represented in the sample. 


\section{Methodology}

Standard IPO event study methodology is followed to compute and test the abnormal returns of the ADR portfolios. The ADR sample includes only firms listed on the New York Stock Exchange. Returns are examined over a 36-month period following the date of issue. The S \& P 500 index is used as a proxy for the market return. Monthly abnormal returns are computed by subtracting each monthly holding period return from that of the S \& P 500 index. Security price and S \& P 500 return data were obtained from Commodity Systems, Inc.

A limitation of the study is that no adjustments are made for economic changes occurring in the sample countries during the investigation period. The focus of the paper is to determine the results that a typical investor would reap by purchasing in a portfolio of financial institution equities from a diversified group of countries during a specified holding period. Including the random events of the countries, perhaps leads to findings that investors generally encounter in the real world.

Equations 1 through 3 describe the process for computing abnormal returns and cumulative abnormal returns for statistical testing. The abnormal return for each security $\mathrm{i}$ on month $\mathrm{t}\left(\mathrm{ar}_{\mathrm{it}}\right)$ is computed as the difference between the return of the security on month $\mathrm{t}\left(\mathrm{r}_{\mathrm{it}}\right)$ and the return of the market on month $\mathrm{t}\left(\mathrm{r}_{\mathrm{mt}}\right)$ as shown in equation 1 below.

$$
a r_{i t}=r_{i t}-r_{m t}
$$

Equation 2 computes the average abnormal return for the sample for month $t$ $\left(A R_{t}\right)$ as the simple average of the sum of the abnormal returns of each of the $n$ securities during month $\mathrm{t}$.

$$
A R_{t}=\frac{1}{n} \sum_{i=1}^{n} a r_{i t}
$$

Cumulative abnormal returns as of month $\mathrm{s}$ are computed as the summation of the average abnormal returns starting at month 1 until month $\mathrm{s}$ in Equation 3.

$$
C A R_{1, s}=\sum_{t=1}^{s} A R_{t}
$$

Monthly average abnormal returns and the cumulative abnormal returns are tested to determine significance using a Z-score. The respective $\mathrm{p}$-values for these tests are given in the findings. A p-value of .10 or less indicates the abnormal return or cumulative abnormal return is significantly different from 0 .

\section{Findings}

Findings suggest that over the 36-month period, cumulative abnormal returns for the entire sample of 58 foreign finance industry equities tend to slightly outperform the $\mathrm{S}$ \& P 500 with a cumulative abnormal gain of 4.32 percent. However, none of the cumulative abnormal returns during the 3 -year period are significant. Table 2 shows the 
month by month abnormal returns, the cumulative abnormal returns, and the respective Pvalues. After the first month of trading the data show a -0.47 percent lower return than the S \& P 500 market return. During 14 of the first 16 months, the ADRs performed worse than the market with negative cumulative abnormal returns as low as -3.44 percent. Positive cumulative returns occur primarily during the last 20 months. This leads to the question of whether a difference exists between ADRs from firms headquartered in emerging markets and those from developed markets.

Table 2, in the center and right columns, show the abnormal and cumulative abnormal returns by month for the finance industry ADRs from emerging markets and developed markets. Cumulative abnormal returns from emerging markets are consistently negative for each of the 36-months which dropped as low as -24.16 percent below the performance of the market. Of the 36 months, 7 months of the emerging market ADRs show significant under-performance. On the other hand, ADRs from developed markets are positive (except for month 11) and reach cumulative abnormal returns as high as 16.96 percent by the $35^{\text {th }}$ month. The 3 -year period ended with a significant 15.17 gain. Twenty-one months of the 36 produce positive cumulative abnormal returns that are significant. Further investigation into whether initial public offerings differ from seasoned equity offerings may also be helpful for investors of foreign equities.

Although the sample of 58 issues exhibit mixed results that range from a high cumulative return of $8.05 \%$ to a low cumulative return of $-3.44 \%$ with a final 36 -month cumulative gain of merely $4.32 \%$, Table 3 provides an interesting breakdown of ADR performance by IPOs and SEOs. The data show a clear and distinct difference between the performance of initial public offerings and seasoned equity offerings. The New York Stock Exchange considers a foreign firm's first equity issue in the United States an initial public offering (IPO). Foreign firms with shares already trading in the United States that issue ADRs are considered seasoned equity offerings (SEOs). The IPO cumulative abnormal returns are consistently negative throughout the 3-year period and finish with a $-9.94 \%$ loss. Four months of the negative cumulative returns are significant. In contrast, the SEOs ended the 3-year period with cumulative gains of $20.69 \%$. The first month, the $18^{\text {th }}, 19^{\text {th }}, 20^{\text {th }}$ month, and the last year produce gains that are significant.

\section{Summary and Conclusions}

Overall, the sample of 58 foreign finance industry ADRs exhibit only mixed results with no significant cumulative abnormal returns. During the first 12 months the ADRs perform poorly relative to the $\mathrm{S} \& \mathrm{P} 500$ index producing a $-2.46 \%$ cumulative abnormal return. Slight insignificant gains occur in the final 24-months ending with a modest $4.32 \%$ 3-year cumulative abnormal return. These findings are in sharp contrast to those of Callaghan, Kleiman, and Sahu (Winter, 2000) who examined 66 ADRs from 18 countries that traded on the NYSE. The authors report cumulative abnormal returns of $19.6 \%$ for the first year. On the other hand, Foerster and Karolyi (2000) and Ritter (1991) discover that ADRs under-perform the market during the 3-year period from date 
of issue. The financial institutions industry tends to perform in the middle of the extremes found in former studies that are based on multi-industry portfolios.

A closer look at the foreign finance industry ADRs reveals that equities from developed countries tend to out-perform those from emerging markets. Furthermore, seasoned equity offerings out-performed the initial public offerings. These findings are contrary to other studies that show positive abnormal returns for unseasoned initial public offerings (Ritter, 1984, McDonald and Fisher, 1972, Martell, Rodriguez and Webb, 1999, Jayaraman, Shastri and Tandon, 1993, and Dawson, 1987). On the other hand, the findings are consistent with studies by Ritter (1991), Brav and Gompers (1997), Ben Naceur (2000), Aggarwal, Leal and Herandez (1993), Levis (1993), and Huang (1999).

This study, however, tends to suggest that the nature of the financial industry itself with firms such as insurance companies, banks, and financial services companies are unique businesses that perform best in developed markets. Investors perhaps try to minimize their risk by purchasing finance industry ADRs that are seasoned rather than new and unproven issues. Because of the apparent asymmetric information between investors in the United States and foreign companies, the results tend to provide further evidence that a completely efficient market does not exist in the international markets.

Overall, the implications are that investors must be selective in choosing their foreign equity portfolio. This study shows that financial industry ADRs that are seasoned equity offerings and those that are from developed markets generally tend to out-perform the S \& P 500 index while IPOs and equities from emerging markets typically underperform the market.

Table 1

Survey Sample Of Foreign Finance Industry Stocks Issued From January 1987 September 2000 by Country

Argentina: 3 Issues

Australia: 3 Issues

Bermuda: 8 Issues

Brazil: 1 Issue

Canada: 10 Issues

Chile: 6 Issues

Columbia: 1 Issue

France: 2 Issues

Greece: 1 Issue

India: 1 Issue

Ireland: 2 Issues

Total: 58 Issues from 22 Countries
Italy: 1 Issue

Japan: 1 Issue

Luxembourg: 1 Issue

Netherlands: 3 Issues

Panama: 1 Issue

Peru: 1 Issue

Portugal: 1 Issue

Puerto Rico: 3 Issues

Spain: 2 Issues

Switzerland: 1 Issue

United Kingdom: 5 Issues 
Table 2

Long-term Return Performance by Month for Finance Industry ADRs Broken Down by Developed and Emerging Market Issues (January $1987-$ September 2000) ${ }^{\mathrm{a}}$

\begin{tabular}{|c|c|c|c|c|c|c|c|c|c|c|c|c|}
\hline \multirow[b]{2}{*}{ Month } & \multicolumn{4}{|c|}{$\begin{array}{l}\text { Entire Finance ADR Sample } \\
\text { (58 Observations) }\end{array}$} & \multicolumn{4}{|c|}{$\begin{array}{l}\text { Finance ADRs From Emerging Markets } \\
\text { (16 Observations) }\end{array}$} & \multicolumn{4}{|c|}{$\begin{array}{l}\text { Finance ADRs From Developed Markets } \\
\text { (42 Observations) }\end{array}$} \\
\hline & AR & P-value & CAR & P-value & AR & P-value & CAR & P-value & AR & $\mathrm{P}$-value & CAR & P-value \\
\hline+1 & $-0.47 \%$ & 0.37 & $-0.47 \%$ & 0.37 & $-2.21 \%$ & 0.30 & $-2.21 \%$ & 0.30 & $0.19 \%$ & 0.44 & $0.19 \%$ & 0.44 \\
\hline+2 & $0.47 \%$ & 0.36 & $0.00 \%$ & 0.50 & $-2.05 \%$ & 0.25 & $-4.25 \%$ & 0.20 & $1.44 \%$ & 0.15 & $1.62 \%$ & 0.19 \\
\hline+3 & $-0.50 \%$ & 0.67 & $-0.50 \%$ & 0.41 & $-6.82 \%$ & 0.00 & $-11.07 \%$ & 0.03 & $1.91 \%$ & 0.04 & $3.53 \%$ & 0.05 \\
\hline+4 & $-2.17 \%$ & 0.02 & $-2.67 \%$ & 0.14 & $-4.82 \%$ & 0.03 & $-15.89 \%$ & 0.01 & $-1.16 \%$ & 0.14 & $2.37 \%$ & 0.16 \\
\hline+5 & $2.88 \%$ & 0.04 & $0.21 \%$ & 0.47 & $7.89 \%$ & 0.05 & $-8.00 \%$ & 0.16 & $0.97 \%$ & 0.22 & $3.34 \%$ & 0.11 \\
\hline+6 & $-0.81 \%$ & 0.26 & $-0.60 \%$ & 0.43 & $-2.30 \%$ & 0.25 & $-10.30 \%$ & 0.12 & $-0.25 \%$ & 0.42 & $3.09 \%$ & 0.15 \\
\hline+7 & $-0.40 \%$ & 0.37 & $-1.00 \%$ & 0.39 & $1.93 \%$ & 0.28 & $-8.37 \%$ & 0.19 & $-1.28 \%$ & 0.11 & $1.81 \%$ & 0.29 \\
\hline+8 & $0.29 \%$ & 0.40 & $-0.71 \%$ & 0.42 & $1.91 \%$ & 0.21 & $-6.46 \%$ & 0.25 & $-0.33 \%$ & 0.40 & $1.48 \%$ & 0.33 \\
\hline+9 & $0.36 \%$ & 0.38 & $-0.35 \%$ & 0.46 & $2.65 \%$ & 0.12 & $-3.81 \%$ & 0.35 & $-0.52 \%$ & 0.34 & $0.96 \%$ & 0.40 \\
\hline+10 & $-1.02 \%$ & 0.13 & $-1.38 \%$ & 0.36 & $-2.27 \%$ & 0.17 & $-6.08 \%$ & 0.28 & $-0.55 \%$ & 0.27 & $0.41 \%$ & 0.46 \\
\hline+11 & $-2.06 \%$ & 0.06 & $-3.44 \%$ & 0.20 & $-5.97 \%$ & 0.05 & $-12.06 \%$ & 0.14 & $-0.57 \%$ & 0.30 & $-0.15 \%$ & 0.48 \\
\hline+12 & $0.97 \%$ & 0.22 & $-2.46 \%$ & 0.29 & $-0.26 \%$ & 0.47 & $-12.32 \%$ & 0.15 & $1.45 \%$ & 0.06 & $1.29 \%$ & 0.37 \\
\hline+13 & $0.40 \%$ & 0.39 & $-2.07 \%$ & 0.33 & $-1.30 \%$ & 0.34 & $-13.62 \%$ & 0.13 & $1.04 \%$ & 0.24 & $2.34 \%$ & 0.29 \\
\hline+14 & $1.66 \%$ & 0.07 & $-0.41 \%$ & 0.47 & $-0.58 \%$ & 0.41 & $-14.20 \%$ & 0.12 & $2.52 \%$ & 0.02 & $4.85 \%$ & 0.14 \\
\hline+15 & $-0.96 \%$ & 0.28 & $-1.37 \%$ & 0.39 & $-8.50 \%$ & 0.02 & $-22.71 \%$ & 0.04 & $1.91 \%$ & 0.10 & $6.76 \%$ & 0.08 \\
\hline+16 & $-0.51 \%$ & 0.36 & $-1.88 \%$ & 0.36 & $0.84 \%$ & 0.43 & $-21.86 \%$ & 0.06 & $-1.02 \%$ & 0.17 & $5.74 \%$ & 0.12 \\
\hline+17 & $2.85 \%$ & 0.01 & $0.97 \%$ & 0.43 & $6.72 \%$ & 0.02 & $-15.14 \%$ & 0.14 & $1.37 \%$ & 0.13 & $7.11 \%$ & 0.08 \\
\hline+18 & $-0.72 \%$ & 0.24 & $0.25 \%$ & 0.48 & $-2.97 \%$ & 0.12 & $-18.11 \%$ & 0.11 & $0.13 \%$ & 0.45 & $7.24 \%$ & 0.08 \\
\hline+19 & $0.05 \%$ & 0.49 & $0.30 \%$ & 0.48 & $-1.41 \%$ & 0.36 & $-19.52 \%$ & 0.10 & $0.61 \%$ & 0.31 & $7.85 \%$ & 0.07 \\
\hline+20 & $1.04 \%$ & 0.26 & $1.34 \%$ & 0.41 & $1.97 \%$ & 0.36 & $-17.55 \%$ & 0.13 & $0.69 \%$ & 0.26 & $8.53 \%$ & 0.06 \\
\hline+21 & $-1.66 \%$ & 0.08 & $-0.32 \%$ & 0.48 & $-5.67 \%$ & 0.04 & $-23.22 \%$ & 0.08 & $-0.13 \%$ & 0.45 & $8.40 \%$ & 0.06 \\
\hline+22 & $1.21 \%$ & 0.16 & $0.89 \%$ & 0.44 & $1.57 \%$ & 0.31 & $-21.65 \%$ & 0.09 & $1.07 \%$ & 0.20 & $9.47 \%$ & 0.04 \\
\hline+23 & $-0.45 \%$ & 0.35 & $0.44 \%$ & 0.47 & $5.00 \%$ & 0.05 & $-16.65 \%$ & 0.16 & $-2.52 \%$ & 0.01 & $6.95 \%$ & 0.11 \\
\hline+24 & $1.88 \%$ & 0.05 & $2.32 \%$ & 0.36 & $2.52 \%$ & 0.16 & $-14.13 \%$ & 0.20 & $1.64 \%$ & 0.09 & $8.59 \%$ & 0.07 \\
\hline+25 & $1.13 \%$ & 0.15 & $3.45 \%$ & 0.30 & $2.53 \%$ & 0.19 & $-11.60 \%$ & 0.25 & $0.59 \%$ & 0.28 & $9.18 \%$ & 0.06 \\
\hline+26 & $0.53 \%$ & 0.34 & $3.98 \%$ & 0.27 & $0.11 \%$ & 0.49 & $-11.49 \%$ & 0.26 & $0.69 \%$ & 0.30 & $9.87 \%$ & 0.05 \\
\hline+27 & $-1.51 \%$ & 0.13 & $2.47 \%$ & 0.36 & $-2.95 \%$ & 0.09 & $-14.44 \%$ & 0.21 & $-0.96 \%$ & 0.28 & $8.91 \%$ & 0.08 \\
\hline
\end{tabular}




\begin{tabular}{|c|c|c|c|c|c|c|c|c|c|c|c|c|}
\hline+28 & $1.06 \%$ & 0.23 & $3.53 \%$ & 0.30 & $-0.09 \%$ & 0.49 & $-14.53 \%$ & 0.21 & $1.50 \%$ & 0.17 & $10.41 \%$ & 0.05 \\
\hline+29 & $-0.39 \%$ & 0.36 & $3.14 \%$ & 0.32 & $0.35 \%$ & 0.44 & $-14.17 \%$ & 0.22 & $-0.67 \%$ & 0.30 & $9.74 \%$ & 0.07 \\
\hline+30 & $0.63 \%$ & 0.32 & $3.77 \%$ & 0.30 & $0.30 \%$ & 0.47 & $-13.87 \%$ & 0.23 & $0.75 \%$ & 0.28 & $10.49 \%$ & 0.06 \\
\hline+31 & $0.63 \%$ & 0.31 & $4.40 \%$ & 0.27 & $0.55 \%$ & 0.44 & $-13.32 \%$ & 0.24 & $0.66 \%$ & 0.29 & $11.16 \%$ & 0.05 \\
\hline+32 & $0.32 \%$ & 0.37 & $4.72 \%$ & 0.26 & $0.15 \%$ & 0.48 & $-13.17 \%$ & 0.24 & $0.38 \%$ & 0.35 & $11.54 \%$ & 0.05 \\
\hline+33 & $1.78 \%$ & 0.18 & $6.50 \%$ & 0.19 & $0.17 \%$ & 0.48 & $-13.00 \%$ & 0.25 & $2.40 \%$ & 0.16 & $13.94 \%$ & 0.03 \\
\hline+34 & $1.55 \%$ & 0.17 & $8.05 \%$ & 0.15 & $-1.30 \%$ & 0.38 & $-14.30 \%$ & 0.23 & $2.63 \%$ & 0.05 & $16.57 \%$ & 0.01 \\
\hline+35 & $-2.37 \%$ & 0.04 & $5.68 \%$ & 0.23 & $-9.62 \%$ & 0.00 & $-23.92 \%$ & 0.11 & $0.39 \%$ & 0.38 & $16.96 \%$ & 0.01 \\
\hline+36 & $-1.36 \%$ & 0.13 & $4.32 \%$ & 0.29 & $-0.24 \%$ & 0.44 & $-24.16 \%$ & 0.11 & $-1.79 \%$ & 0.12 & $15.17 \%$ & 0.03 \\
\hline
\end{tabular}

Note: P-values in bold italics represent returns significant at the .10 level. 
Table 3

Long-term Return Performance by Month for Finance Industry ADRs Broken Down by Initial Public Offerings and Seasoned Equity Offerings (January 1987 - September 2000) ${ }^{\mathrm{a}}$

\begin{tabular}{|c|c|c|c|c|c|c|c|c|c|c|}
\hline \multirow[b]{2}{*}{ Month } & \multicolumn{4}{|c|}{$\begin{array}{c}\text { Entire Finance ADR Sample } \\
\text { (58 Observations) }\end{array}$} & \multicolumn{4}{|c|}{$\begin{array}{c}\text { Finance Industy ADR IPOs } \\
(31 \text { Observations })\end{array}$} & \multicolumn{2}{|c|}{$\begin{array}{r}\text { Finand } \\
(2\end{array}$} \\
\hline & AR & P-value & CAR & $\mathrm{P}$-value & AR & P-value & CAR & $\mathrm{P}$-value & AR & $\mathrm{P}$ \\
\hline+1 & $-0.47 \%$ & 0.37 & $-0.47 \%$ & 0.37 & $-3.10 \%$ & 0.08 & $-3.10 \%$ & 0.08 & $2.54 \%$ & \\
\hline+2 & $0.47 \%$ & 0.36 & $0.00 \%$ & 0.50 & $1.97 \%$ & 0.16 & $-1.13 \%$ & 0.35 & $-1.24 \%$ & \\
\hline+3 & $-0.50 \%$ & 0.67 & $-0.50 \%$ & 0.41 & $-2.48 \%$ & 0.07 & $-3.61 \%$ & 0.15 & $1.77 \%$ & \\
\hline+4 & $-2.17 \%$ & 0.02 & $-2.67 \%$ & 0.14 & $-1.97 \%$ & 0.09 & $-5.58 \%$ & 0.07 & $-2.40 \%$ & \\
\hline+5 & $2.88 \%$ & 0.04 & $0.21 \%$ & 0.47 & $2.43 \%$ & 0.19 & $-3.14 \%$ & 0.25 & $3.39 \%$ & \\
\hline+6 & $-0.81 \%$ & 0.26 & $-0.60 \%$ & 0.43 & $0.16 \%$ & 0.47 & $-2.99 \%$ & 0.28 & $-1.93 \%$ & \\
\hline+7 & $-0.40 \%$ & 0.37 & $-1.00 \%$ & 0.39 & $1.43 \%$ & 0.23 & $-1.56 \%$ & 0.39 & $-2.49 \%$ & \\
\hline+8 & $0.29 \%$ & 0.40 & $-0.71 \%$ & 0.42 & $-0.56 \%$ & 0.38 & $-2.12 \%$ & 0.35 & $1.27 \%$ & \\
\hline+9 & $0.36 \%$ & 0.38 & $-0.35 \%$ & 0.46 & $0.44 \%$ & 0.39 & $-1.69 \%$ & 0.39 & $0.26 \%$ & \\
\hline+10 & $-1.02 \%$ & 0.13 & $-1.38 \%$ & 0.36 & $-2.40 \%$ & 0.01 & $-4.09 \%$ & 0.25 & $0.55 \%$ & \\
\hline+11 & $-2.06 \%$ & 0.06 & $-3.44 \%$ & 0.20 & $-4.31 \%$ & 0.00 & $-8.40 \%$ & 0.09 & $0.53 \%$ & \\
\hline+12 & $0.97 \%$ & 0.22 & $-2.46 \%$ & 0.29 & $0.66 \%$ & 0.38 & $-7.74 \%$ & 0.12 & $1.34 \%$ & \\
\hline+13 & $0.40 \%$ & 0.39 & $-2.07 \%$ & 0.33 & $0.03 \%$ & 0.49 & $-7.72 \%$ & 0.13 & $0.82 \%$ & \\
\hline+14 & $1.66 \%$ & 0.07 & $-0.41 \%$ & 0.47 & $1.57 \%$ & 0.16 & $-6.15 \%$ & 0.19 & $1.76 \%$ & \\
\hline+15 & $-0.96 \%$ & 0.28 & $-1.37 \%$ & 0.39 & $-2.17 \%$ & 0.20 & $-8.32 \%$ & 0.13 & $0.43 \%$ & \\
\hline+16 & $-0.51 \%$ & 0.36 & $-1.88 \%$ & 0.36 & $-1.52 \%$ & 0.24 & $-9.84 \%$ & 0.10 & $0.65 \%$ & \\
\hline+17 & $2.85 \%$ & 0.01 & $0.97 \%$ & 0.43 & $4.75 \%$ & 0.01 & $-5.09 \%$ & 0.26 & $0.66 \%$ & \\
\hline+18 & $-0.72 \%$ & 0.24 & $0.25 \%$ & 0.48 & $-2.21 \%$ & 0.07 & $-7.30 \%$ & 0.19 & $0.98 \%$ & \\
\hline+19 & $0.05 \%$ & 0.49 & $0.30 \%$ & 0.48 & $-1.19 \%$ & 0.30 & $-8.50 \%$ & 0.16 & $1.48 \%$ & \\
\hline+20 & $1.04 \%$ & 0.26 & $1.34 \%$ & 0.41 & $1.19 \%$ & 0.33 & $-7.31 \%$ & 0.21 & $0.87 \%$ & \\
\hline+21 & $-1.66 \%$ & 0.08 & $-0.32 \%$ & 0.48 & $-0.95 \%$ & 0.24 & $-8.26 \%$ & 0.18 & $-2.47 \%$ & \\
\hline+22 & $1.21 \%$ & 0.16 & $0.89 \%$ & 0.44 & $1.98 \%$ & 0.17 & $-6.28 \%$ & 0.25 & $0.32 \%$ & \\
\hline+23 & $-0.45 \%$ & 0.35 & $0.44 \%$ & 0.47 & $1.96 \%$ & 0.14 & $-4.32 \%$ & 0.32 & $-3.21 \%$ & \\
\hline+24 & $1.88 \%$ & 0.05 & $2.32 \%$ & 0.36 & $0.22 \%$ & 0.44 & $-4.10 \%$ & 0.33 & $3.80 \%$ & \\
\hline+25 & $1.13 \%$ & 0.15 & $3.45 \%$ & 0.30 & $1.49 \%$ & 0.19 & $-2.62 \%$ & 0.39 & $0.71 \%$ & \\
\hline+26 & $0.53 \%$ & 0.34 & $3.98 \%$ & 0.27 & $-0.77 \%$ & 0.34 & $-3.39 \%$ & 0.37 & $2.02 \%$ & \\
\hline+27 & $-1.51 \%$ & 0.13 & $2.47 \%$ & 0.36 & $-3.45 \%$ & 0.03 & $-6.84 \%$ & 0.25 & $0.72 \%$ & \\
\hline+28 & $1.06 \%$ & 0.23 & $3.53 \%$ & 0.30 & $1.78 \%$ & 0.23 & $-5.06 \%$ & 0.31 & $0.24 \%$ & \\
\hline+29 & $-0.39 \%$ & 0.36 & $3.14 \%$ & 0.32 & $-1.92 \%$ & 0.11 & $-6.98 \%$ & 0.25 & $1.37 \%$ & \\
\hline+30 & $0.63 \%$ & 0.32 & $3.77 \%$ & 0.30 & $0.83 \%$ & 0.36 & $-6.14 \%$ & 0.28 & $0.39 \%$ & \\
\hline+31 & $0.63 \%$ & 0.31 & $4.40 \%$ & 0.27 & $1.23 \%$ & 0.29 & $-4.92 \%$ & 0.33 & $-0.05 \%$ & \\
\hline+32 & $0.32 \%$ & 0.37 & $4.72 \%$ & 0.26 & $-0.67 \%$ & 0.32 & $-5.59 \%$ & 0.31 & $1.45 \%$ & \\
\hline+33 & $1.78 \%$ & 0.18 & $6.50 \%$ & 0.19 & $0.57 \%$ & 0.37 & $-5.02 \%$ & 0.33 & $3.18 \%$ & \\
\hline+34 & $1.55 \%$ & 0.17 & $8.05 \%$ & 0.15 & $0.50 \%$ & 0.41 & $-4.52 \%$ & 0.35 & $2.75 \%$ & \\
\hline+35 & $-2.37 \%$ & 0.04 & $5.68 \%$ & 0.23 & $-3.99 \%$ & 0.01 & $-8.51 \%$ & 0.23 & $-0.51 \%$ & \\
\hline+36 & $-1.36 \%$ & 0.13 & $4.32 \%$ & 0.29 & $-1.43 \%$ & 0.12 & $-9.94 \%$ & 0.19 & $-1.29 \%$ & \\
\hline
\end{tabular}

Note: P-values in bold italics represent returns significant at the .10 level. 


\section{References}

Aggarwal, R., R. Leal and L. Hernandez. "The Aftermarket Performance of Initial Public Offerings in Latin America." Financial Management Vol. 22 (Spring 1993), pp. 42-53.

Ben Naceur, S. "An Examination of the Tunisian IPO Pricing in the Short and Long Run: 1992-1997." Applied Economics Letters Vol. 7 (2000), pp. 293-296.

Besley, Scott and Brigham, Eugene F., Principles of Finance, The Dryden Press, New York, 1999, p126.

Brav, A. and P. Gompers. "Myth or Reality? The Long-Run Underperformance of Initial Public Offerings: Evidence from Venture and Nonventure Capital-Backed Companies." Journal of Finance Vol. 52 (December 1997), pp. 1791-1821.

Brigham, Eugene, F. and Ehrhardt, Michael C., Financial Management, 11 Edition, South-Western Publishers, Mason, Ohio, 2005, p. 900.

Callaghan, J., R. Kleiman and A. Sahu. "The Market-Adjusted Investment Performance of ADR IPOs and SEOs." Global Finance Journal Vol. 10 (Fall 1999/Winter 2000), pp. 123-145.

Dawson, S. "The Secondary Stock Market Performance of Initial Public Offerings in Hong Kong, Singapore and Malaysia: 1978-1984." Journal of Business, Finance \& Accounting (1987), pp. 65-76.

Drexhage, G. "How to Pay for Your Next US Takeover: Use ADRs." Corporate Finance (October 1998), pp. 22-30.

Foerster, S. and G. Andrew Karolyi. "The Long-Run Performance of Global Equity Offerings." Journal of Financial \& Quantitative Analysis Vol. 35 (December 2000), pp. 499-528.

Huang, Y. "The Price Behavior of Initial Public Offerings on the Taiwan Stock Exchange." Applied Financial Economics Vol. 9 (1999), pp. 201-208.

Jayaraman, N., K. Shastri and K. Tandon. "The Impact of International Cross Listings on Risk and Return: the Evidence from American Depository Receipts." Journal of Banking \& Finance Vol. 17 (1993), pp. 91-103.

Jiang, C. "Diversification with American Depository Receipts: The Dynamics and the Pricing Factors." Journal of Business, Finance \& Accounting Vol. 25 (June/July 1998), pp. 683-699. 
Levis, M. "The Long-Run Performance of Initial Public Offerings: The UK Experience 1980-1988." Financial Management Vol. 22 (Spring 1993), pp. 28-42.

Liang, Y. and M. Mougoue. "The Pricing of Foreign Exchange Risk: Evidence from ADRs." International Review of Economics and Finance Vol. 5 (1996), pp. 377-385.

Martell, T., L. Rodriguez, Jr. and G. Webb. "The Impact of Listing Latin American ADRs on the Risks and Returns of the Underlying Shares." Global Finance Journal Vol. 10 (Fall/Winter 1999), pp. 147-160.

McDonald, J. and A. Fisher. "New-Issue Stock Price Behavior." Journal of Finance (March 1972), pp.97-102.

Officer, D. and R. Hoffmeister. “ADRs: A Substitute for the Real Thing?" Journal of Portfolio Management (Winter 1988), pp. 61-65.

Ritter, J. "The 'Hot Issue' Market of 1980." Journal of Business Vol. 57 (1984), pp. 215240.

Ritter, J. "The Long-Run Performance of Initial Public Offerings." Journal of Finance Vol. 46 (March 1991), pp. 3-27.

Shearer, B. "ADRs Grow as an Acquisition Currency." Mergers \& Acquisitions: The Dealer maker's Journal Vol. 36 (April 2001), pp. 6-10.

Sundaram, A. and D. Logue. "Valuation Effects of Foreign Company Listings on U.S. Exchanges." Journal of International Business Studies Vol. 27 (1996), pp. 67-89. 